\title{
DIABETIC POLYNEUROPATHY AND RISK OF FALLS: FEAR OF FALLING AND OTHER FACTORS
}

\author{
Vesna Bokan-Mirković1,2, Željana Škarić-Karanikić ${ }^{2}$ Sonja Nejkov², \\ Marina Vukovići ${ }^{1,2}$ and Dragana Ćirović ${ }^{3}$ \\ ${ }^{1}$ Faculty of Medicine, University of Montenegro, Podgorica, Montenegro; \\ ${ }^{2}$ Clinical Center of Montenegro, Podgorica, Montenegro; ${ }^{3}$ University Children's Hospital, Belgrade, Serbia
}

\begin{abstract}
SUMMARY - The aim of the study was to analyze postural stability, walking speed and fear of falling in patients with diabetic polyneuropathy (DPN) in order to determine the risk factors for falls, as well as the effect of DPN characteristics as additional factors. A sample of 48 patients with type 2 diabetes and DPN were enrolled in this non-randomized observational study. The patients were divided into two groups of fallers and non-fallers. All subjects underwent evaluation with the Functional Reach Test (FRT), Tinetti Falls Efficacy Scale (Tinetti FES) and 10-Meter Walk Test (10MWT). Neuropathy was quantified with the Michigan Neuropathy Screening Instrument (MNSI, Questionnaire part) and 5.07/10-g Semmes Weinstein monofilament examination (SW-ME). The 10MWT and SW-ME were significantly different between the faller and non-faller groups $(\mathrm{p}<0.05)$. Duration of DPN correlated positively with SW-ME $(p=0.005)$ in the faller group. FES showed significant positive correlation with MNSI and negative correlation with 10MWT in the non-faller group. Logistic regression analysis revealed that SW-ME was significantly associated with the probability of falling $(\mathrm{p}=0.0076 ; \mathrm{OR}=1.378)$. Study results suggested that the loss of protective sensitivity of foot could be a risk factor for falls in people suffering from type 2 diabetes.
\end{abstract}

Key words: Diabetes mellitus; Diabetic neuropathies; Risk; Accidental falls; Postural balances

\section{Introduction}

The causes of falls are multifactorial in people with diabetes ${ }^{1}$. The annual incidence rate of falls in people with diabetes older than 55 is $35 \%$ and in those over 65 it is $39 \% \%^{2,3}$. An important potential risk factor for falls is diabetic polyneuropathy (DPN), which is present in half of people with diabetes ${ }^{4}$. In 2008, a report by the Quality Standards Subcommittee of the American Academy of Neurology indicated that people with peripheral neuropathy had a probable (level B evidence) risk of fall ${ }^{5}$. Different possible risk factors that can cause fall in people with diabetes and DPN

Correspondence to: Vesna Bokan-Mirkovic, MD, PhD, Faculty of Medicine, University of Montenegro, Clinical Center of Montenegro, Center for Physical Medicine and Rehabilitation, Ljubljanska bb, Podgorica, Montenegro

E-mail: vesnabokanmir@gmail.com

Received February 14, 2017, accepted June 9, 2017 have been examined so far. The problem of balance in elderly people with type 2 diabetes has often been reported as a significant risk $^{2}$. In addition to reduced proprioceptive inputs, neuropathic symptoms also play a role in the decrease of walking speed. Balance problems are also caused by biomechanical structural disorders, limited joint mobility and distal weakness ${ }^{6,7}$. In previous studies, the reduced sensitivity of foot and pain were the risk factors of diabetic foot, but there are not enough data to prove that these symptoms predict falls in people with diabetes. Examination of lower limb usually shows sensory loss of vibration, pressure, pain, and temperature perception (mediated by small and large fibers) and absent ankle reflexes ${ }^{8}$

People with DPN have a reduced walking speed, as well as other gait alterations ${ }^{6,9}$. Somatosensory losses in legs compromise the functional postural stability and lead to the risk of falling when performing more demanding daily activities ${ }^{9}$. From the aspect of reha- 
bilitation, accurate assessment of balance and dysfunction at walk is important in order to plan the program of exercises ${ }^{9}$. Chau et al. believe that there is a need of forming subgroups of people with diabetes in order to determine a special program of exercises. The reason for this suggestion is the existence of multisystemic impairment in DPN, which can be the cause of fall in people with diabetes ${ }^{10}$. Jernigan et al. ${ }^{11}$ point to the conclusion of a recent systematic literature review that there is a need of research in this area of exercise application in order to prevent falls.

A possible selection of tests to assess balance and stability is suggested in the monographs issued by members of the European Academy of Rehabilitation Medicine $^{12}$ with the aim to identify whether or not a problem exists in order to predict the risk of fall and to determine whether treatment is needed or has been effective.

When setting up a goal, we assumed that in the group of people younger than 70 we reduce the possible changes caused by the aging process, which in the interaction with DPN, could affect the result ${ }^{13}$.

The aim of this study was to analyze postural stability, walking speed and fear of falling to determine predictors of falls in a group of patients with DPN, as well as the impact of DPN characteristics as confounding factors.

\section{Patients and Methods}

The study was approved by the Ethics Committee of the Clinical Center of Montenegro. An informed consent was obtained from all study participants.

\section{Patients}

The study included a group of 48 patients with type 2 diabetes with electromygraphically confirmed DPN, between 35 and 70 years of age, who were referred for outpatient examination at the Center for Physical Medicine and Rehabilitation, Clinical Center of Montenegro in the period from January 2015 to January 2016. Patient data were obtained from medical documentation. Data on diabetes duration and duration of DPN were collected from endocrinologist and neurologist documentation. Glycosylated hemoglobin (HbA1c) was determined within two months. Exclusion criteria were age $>70$, lack of blood sugar control, amputation of foot, musculoskeletal disease, injury that could influence functionality, neurologic and cardiovascular disease, and use of medications that potentially can affect the activities of daily living.

\section{Fall history}

The patients were asked whether they had sustained a fall in the last three years. Study patients were divided according to the history of falls into two groups: non-faller ( 0 fall in the previous three years) and faller (1 or more falls in the previous three years).

\section{Fall risk assessment}

Functional Reach Test (FRT) was selected because it measures some degree of static or dynamic balance and is easily administered in a clinical setting. It is based on analyzing the limits of stability in the absence of external shocks, assessing maximum displacement, intentionally, which can reach a subject without losing balance ${ }^{14}$. Instructions are available at the Rehabilitation Measures Database ${ }^{15}$. Tinetti Falls Efficacy Scale (Tinetti FES) was selected to assess perception of balance and stability during activities of daily living. A 10-item questionnaire is so designed to reveal confidence in their ability to perform 10 daily tasks without falling as an indicator of how one's fear of falling impacts physical performance. Each item is rated from 1 ("very confident") to 10 ("not confident at all"), and per item ratings are added to generate a summary total score. Total scores can range from 10 (best possible) to 100 (worst possible). Thus, lower scores indicate more confidence and higher scores indicate lack of confidence and greater fear of falling. Functional mobility was evaluated by using the 10-Meter Walk Test (10MWT). The aim was to collect results from three trials and calculate the mean of these three trials.

\section{Examination of neuropathy}

All patients were evaluated with the Michigan Neuropathy Screening Instrument (MNSI, Questionnaire part $)^{16}$. The MNSI is an instrument including a questionnaire with 15 questions, with a maximum score of 13. The questionnaire asks about positive (pain, temperature sensation, tingling) and negative (numbness) sensory symptoms, cramps and muscle weakness, foot ulcers or cracks, and amputation. Neuropathy can be defined as seven or more positive responses on the MNSI questionnaire ${ }^{17}$. Monofilament 
Table 1. Comparison of characteristics between faller and non-faller groups

\begin{tabular}{|c|c|c|c|c|c|c|c|c|c|}
\hline & \multicolumn{4}{|c|}{ Faller $(\mathrm{n}=28)$} & \multicolumn{4}{|c|}{ Non-faller $(n=20)$} & \multirow[b]{2}{*}{$p$} \\
\hline & $\mathrm{n}$ & Mean \pm SD & Median & Min-max & $\mathrm{n}$ & Mean \pm SD & Median & Min-max & \\
\hline Female & 12 & & & & 11 & & & & \multirow{2}{*}{0.4064} \\
\hline Male & 16 & & & & 9 & & & & \\
\hline Age (yrs) & & & 63.5 & $37-70$ & & & 65 & $57-70$ & 0.6128 \\
\hline $\mathrm{BMI}\left(\mathrm{kg} / \mathrm{m}^{2}\right)$ & & $25.53 \pm 2.92$ & & & & $26.82 \pm 3.07$ & & & 0.148 \\
\hline Diabetes duration (yrs) & & & 11 & $5-27$ & & & 7.5 & $2-15$ & $0.0024^{*}$ \\
\hline $\begin{array}{l}\text { Duration of non- } \\
\text {-confirmed DPN (yrs) }\end{array}$ & & & & & & & & & \\
\hline $\begin{array}{l}\text { Duration of confirmed } \\
\text { DPN (yrs) }\end{array}$ & & & 6 & $1-15$ & & & 3 & $1-15$ & $0.0487^{*}$ \\
\hline $\mathrm{HbA1c} \%$ & & $6.52 \pm 0.72$ & & & & $6.70 \pm 0.67$ & & & 0.3873 \\
\hline MNSI & & & 8 & 4-11 & & & 6.5 & $3-13$ & 0.1099 \\
\hline Tinetti FES & & & 23 & $12-51$ & & & 18 & $10-51$ & 0.0638 \\
\hline $10 \mathrm{MWT}(\mathrm{m} / \mathrm{s})$ & & & 0.950 & $0.58-1.49$ & & & 1.185 & $0.65-1.85$ & $0.0238^{*}$ \\
\hline $\mathrm{FRT}(\mathrm{cm})$ & & $25.38 \pm 8.13$ & & & & $25.10 \pm 6.14$ & & & 0.8965 \\
\hline SW-ME & & & 4.5 & $0-10$ & & & 1.5 & $0-8$ & $0.0101^{*}$ \\
\hline
\end{tabular}

BMI = body mass index DPN = diabetic polyneuropathy; MNSI = Michigan Neuropathy Screening Instrument; Tinetti FES = Tinetti Falls Efficacy Scale; 10MWT = 10-Meter Walk Test; FRT = Functional Reach Test; SW-ME = 5.07/10-g Semmes Weinstein monofilament examination; ${ }^{\mathrm{p}}<0.05$

sensation was tested with the 5.07/10-g Semmes Weinstein monofilament examination (SW-ME) applied to ten sites per foot. Nine plantar sites (distal great toe, third toe, and fifth toe; first, third, and fifth metatarsal heads; medial foot, lateral foot, and heel) and one dorsal site were tested. The examiner had no information on other results, testing was repeated twice, and the results were estimated with a cut-off of more than 4 sites for the loss of protective sensitivity.

\section{Statistical analysis}

On statistical analysis we used EZR software. Coefficient of variation and quantile-quantile comparison (QQ) plot were used to assess normal distribution compatibility. Mann Whitney test was used to examine difference in age, duration of diabetes, DPN duration, Tinetti FES, MNSI, 10MWT and SW-ME, and two-sample $t$ test for difference in HbA1c and body mass index (BMI) between the non-faller and faller groups. Spearman's rank correlation test was used for analysis of correlation between DPN duration and SW-ME, Tinneti FES and MNSI, Tinneti FES and 10MWT. Logistic regression analysis was performed in order to analyze the relationship between SW-ME and risk of falling. The level of statistical significance was set at $\mathrm{p}<0.05$.

\section{Results}

Patient demographic and clinical data are shown in Table 1. There were no significant differences between the faller and non-faller groups in respect of age, gender, $\mathrm{HbA} 1 \mathrm{c}$ and BMI. Duration of diabetes and duration of confirmed DPN were significantly different between the two groups $(p<0.05)$. In the assessment of the risk of falling, 10MWTand SW-ME were significantly different between the faller and non-faller groups $(\mathrm{p}<0.05)$.

\section{Analysis of results in the faller group}

During the three-year period, 28 participants reported a fall: 14 participants reported one fall; 7 participants reported two falls; and 7 participants reported three and more falls. The median DM duration was 11 (range 5-27) years and duration of DPN confirmed by neurology was 6 (range 1-15) years. The evidence for fear of falling measured by Tinetti FES score was higher in the faller group (23, range 12-51) than in the 
non-faller group (18, range 10-51). The walking speed measured by 10MWT was significantly lower in the faller group as compared with the non-faller group $(0.950$, range $0.58-1.49 ; \mathrm{p}<0.05)$. The mean value of FRT was 25.38 (SD 8.12).

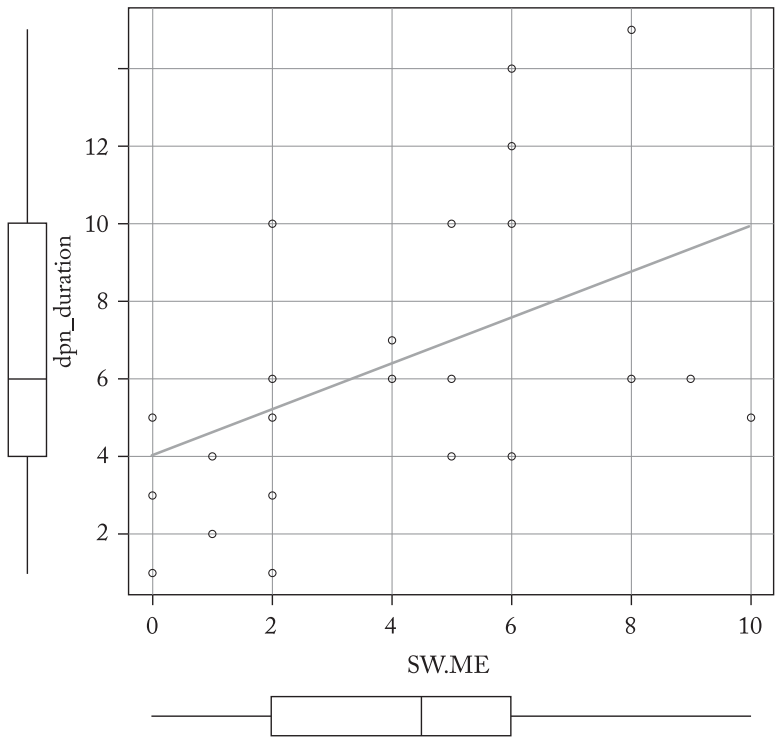

Fig. 1. Correlation between duration of diabetic polyneuropathy (DPN) and 5.07/10-g Semmes Weinstein monofilament examination ( $S W-M E)$ testing in the faller group.

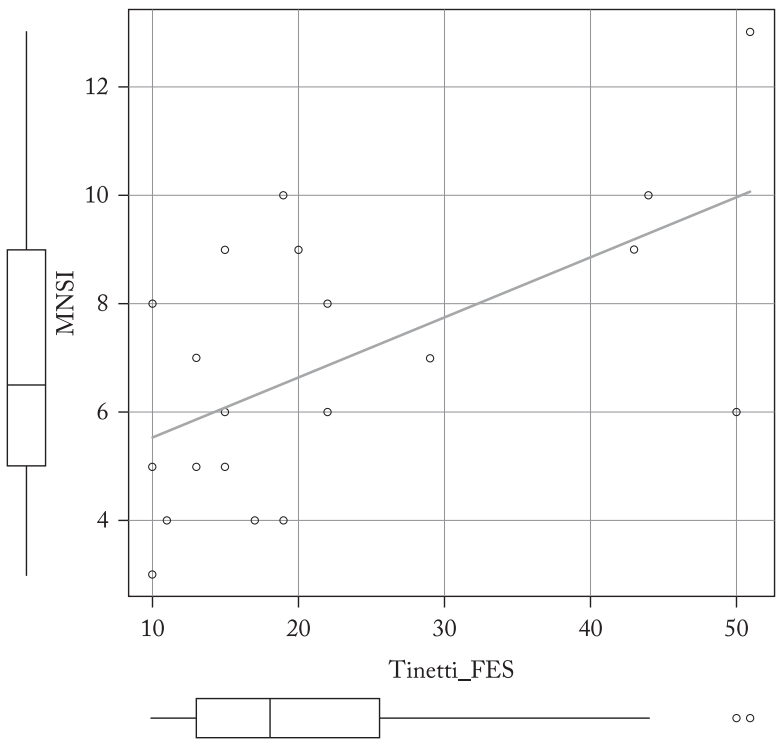

Fig. 2. Correlation between Michigan Neuropathy Screening Instrument (MNSI) and Tinetti Falls Efficacy Scale (FES) in the non-faller group.
Testing of the absence of protective sensitivity (SW-ME) showed the median in patients with a history of falling to be significantly higher (4.5, range $0-10)$ as compared with the non-faller group (1.5, range $0-8 ; p<0.05)$.

\section{Significant correlations within groups}

In the faller group, significant correlation was found between DPN symptom duration and SW-ME

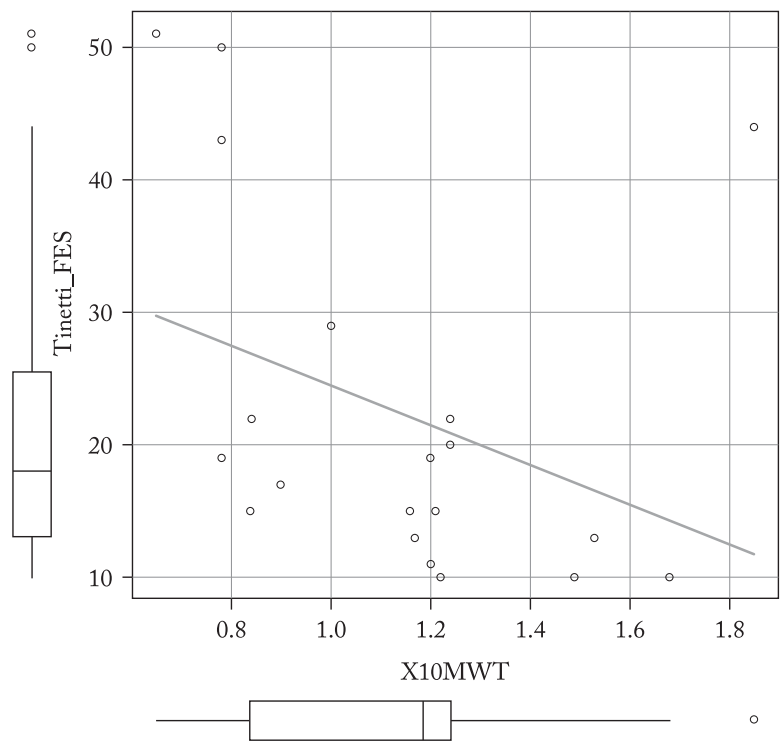

Fig. 3. Correlation between Tinetti Falls Efficacy Scale (FES) and 10-Meter Walk Test (10MWT) in the non-faller group.

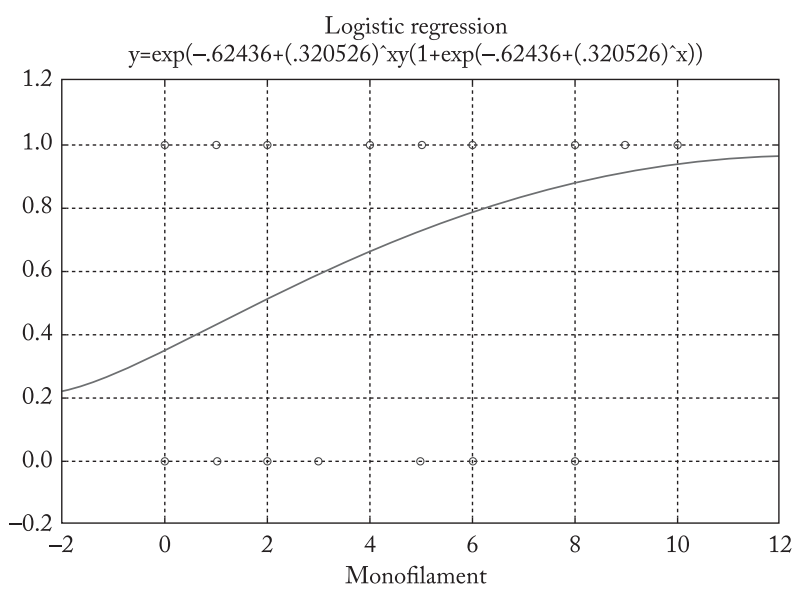

Fig. 4. The output indicates that monofilament is significantly associated with the probability of falling $(p=0.0076$ Wald test); odds ratio unit change is equal to 1.378 . 
testing $(\mathrm{S}=1787.5$, Spearman's rank correlation coefficient $0.511 ; \mathrm{p}=0.00548$ ) (Fig. 1). There was significant correlation between Tinetti FES and MNSI in the non-faller group $(\mathrm{S}=594.2$, Spearman's rank correlation coefficient $0.553 ; \mathrm{p}=0.0114$ ) (Fig. 2). In the nonfaller group, significant negative correlation was recorded between FES and 10MWT ( $\mathrm{S}=1986.9$, Spearman's rank correlation coefficient $-0.494 ; \mathrm{p}=0.0269$ ) (Fig. 3). SW-ME was examined by logistic regression: the output indicated that monofilament was significantly associated with the probability of falling $(p=0.0076$, Wald test $)$. Odds ratio unit change was equal to 1.378 (Fig. 4).

\section{Discussion}

We examined the association between DPN and risk of falls. In order to implement programs for the prevention of falls, it is necessary to identify the risk, taking into account that falling is a complex and multifaceted issue. One group of our patients had problems with postural control according to the results of FRT compared to the cut-off score. Since balance control is a complex entity, it is difficult for a single test to measure all its aspects. Jonsson et al. ${ }^{18}$ suggest that it is important to specify what aspect of balance the test measures and to validate that the test really does reflect this aspect.

In our study, walking speed proved to be a significant characteristic that affects safety in performing the given daily activities. Walking speed was significantly lower in the participants with the history of fall. Measuring of walking speed in patients with DPN is significant because walking capacity and performance are decreased in patients with diabetic complications of the foot ${ }^{19}$. Kanade et al. ${ }^{19}$ suggest that decreased walking speed in patients with DPN matches with reduced plantar pressures at some sites on the foot. When it comes to exercise programs, Allet et al. applied exercise program based on the program of prevention of falls in the elderly population in order to improve walking speed and balance in people with diabetes ${ }^{4}$. Cummning et al. consider that "fear of falling" as a medical problem is as important in the group of non-fallers as in the group of fallers ${ }^{20}$. In our study patients, Tinetti FES showed higher values in the group of fallers but there was no correlation with other variables exam- ined. In patients who had no experience of falling (non-faller group), the expression of fear of falling was associated with decreased walking speed. In the same group, increasing the fear of falling correlated with the higher score of neuropathic symptoms, suggesting that the expression of the fear of falling is a significant problem in patients with DPN. Our study subjects had long-term duration of diabetes and DPN, which was significantly longer in the faller group. Analyzing pain in our study participants, the results of MNSI showed that the presence of pain had high scores, but they were higher in the group of fallers. Neuropathic symptoms can be "totally silent" ${ }^{21}$ or numbness, burning foot pain is more pronounced at night, and can be present at the time of diabetes diagnosis or a few years later. Our results showed that in the group of fallers there was a correlation between the duration of DPN symptoms and loss of foot sensitivity. Evaluation of protective sensitivity by monofilament testing was the subject of examination in a great number of studies ${ }^{22-25}$. In our study, this testing revealed that less than half of the participants in the faller group had insensitivity in more than four examined points on their feet. Armstrong et al. ${ }^{25}$ consider that identification of more than four points is of high sensitivity for detection of patients with a risk of complications of neuropathy in people with diabetes. A positive odds ratio of 1.378 in this study showed that increase in the number of insensitive points on the foot increased the possibility of falling.

This study demonstrated the need for using tests for the risk of falls in patients with DPN and suggested that DPN is a specific entity for planning specific prevention programs of physical therapy and rehabilitation. A limitation of this study was a small number of patients.

\section{Conclusion}

We found a decrease in walking speed to be an important complication that could influence falling in patients with DPN. In patients who have no experience of falling, fear of falling increases with decreasing walking speed. Furthermore, the study suggested that a significant predictive factor for the risk of falling is the lack of protective sensitivity of the foot, which is associated with the duration of DPN. 


\section{References}

1. Crews RT, Yalla SV, Fleischer AE, Wu SC. A growing troubling triad: diabetes, aging and fall. J Aging Res. 2013;342650, http://dx.doi.org/10.1155/2013/342650. Epub 2013 Feb 16

2. Hewston P, Deshpande N. Falls and balance impairments in older adults with type 2 diabetes: thinking beyond diabetic peripheral neuropathy. Can J Diabetes. 2016;1:6-9, http://dx.doi. org/10.1016/j.jcjd.2015.08.005. Epub 2016 Jan 6

3. Tillinq LM, Darawil K, Britton M. Falls as a complication of diabetes mellitus in older people. J Diabetes Complications. 2006;20:158-62, http://dx.doi.org/10.1016/j.jdiacomp. 2005.06.004

4. Allet L, Armand S, De Bie RA, Golay A, Monnin D, Aminian $\mathrm{K}$, et al. The gait and balance of patients with diabetes can be improved: a randomized controlled trial. Diabetologia. 2010;53:458-66, doi: 10.1007/s00125-009-1592-4. Epub 2009 Nov 17

5. Thurman DJ, Stevens JA, Rao JK. Practice parameter: assessing patients in a neurology practice in a risk of falls (an evidence based review): report of the Quality Standards Subcommittee of the American Academy of Neurology. Neurology. 2008;70: 473-9, https://doi.org/: 10.1212/01.wnl.0000299085.18976.20

6. Pan X, Bai J. Balance training in the intervention of fall risk in elderly with diabetic peripheral neuropathy: a review. Int J Nurs Sci. 2014;1(4):441-5. https://doi.org/10.1016/j.ijnss. 2014.09.001

7. Macgilchrist C, Paul L, Ellis BM, Howe TE, Kennon B, Godwin J. Lower-limb risk factors for falls in people with diabetes mellitus. Diabet Med. 2010;27:162-8, doi: 10.1111/j. 1464-5491.2009.02914.x

8. Boulton AJM, Vinik AI, Arezzo JC, Bril V, Feldman EL, Freeman R, et al. Diabetic neuropathies. A statement by the American Diabetes Association. Diabetes Care. 2008;28:956-62, https://doi.org/10.2337/diacare.28.4.956

9. Akbari M, Jafari H, Moshashaee A, Forugh B. Do diabetic neuropathy patients benefit from balance training? J Rehabil Res Dev. 2012;49:333-8, http://dx.doi.org/10.1682/JRRD. 2010.10.0197

10. Chau RSW, Ng TKW, Kwan RLC, Choi CH, Cheing GLY. Risk of fall for people with diabetes. Disabil Rehabil. 2013;23:1975-80, https://doi.org/: 10.3109/09638288.2013. 770079. Epub 2013 Apr 25

11. Jernigan SD, Pohl PS, Mahnken JD, Kluding PM. Diagnostic accuracy of fall risk assessment tools in people with diabetic peripheral neuropathy. Phys Ther. 2012;11:1461-70, doi: 10.2522/ptj.20120070. Epub 2012 Jul 26

12. Nardone A, Schieppati M, Schmid M. Assessment of posture and balance in ageing and disease. In: Barat M, Franchignoni F, editors. Assessment in Physical Medicine and Rehabilitation Views and Perspectives. Pavia: Ed Maugeri Foundation Books, 2004; pp 143-79.

13. Faulkner FA, Redfern MS, Cauley JA, Landsittel DP, Studenski SA, Rosano C, Simonsick EM, Harris TB, Shorr RI, Ayo- nayon HN, Newman AB. Health, Aging, and Body Composition Study. Multitasking: association between poorer performance and a history of recurrent falls. J Am Geriatr Soc. 2007;55:570-6, doi: 10.1111/j.1532-5415.2007.01147.x

14. Merchán-Baeza JA, González-Sánchez M, Cuesta-Vargas AI. Reliability in the parameterization of the functional reach test in elderly stroke patients: a pilot study. Biomed Res Int. 2014;2014:637671, http://dx.doi.org/10.1155/2014/637671

15. Rehab Measures: Functional Reach Test/Modified Functional Reach Test (2013). Available at: www.rehabmeasures.org/ Lists/RehabMeasures/PrintView.aspx?ID=950

16. Michigan Neuropathy Screening Instrument, produced by the Michigan Diabetes Research and Training Centre. Available at: http://www.med.umich.edu/mdrtc/survey/index.html\#mnsi. Accessed 1 March 2002.

17. Al Geffari M. Comparison of different screening tests for diagnosis of diabetic neuropathy in primary health care setting. Int J Health Sci (Qassim). 2012;6:127-34. PMC3616942

18. Jonsson E, Henriksson M, Hirschfeld H. Does the Functional Reach Test reflect stability limits in elderly people? J Rehabil Med. 2002;35:26-30.

19. Kanade RV, Van Deursen RWM, Harding K, Price P. Walking performance in people with diabetic neuropathy: benefits and treats. Diabetologia. 2006;49:1747-54. doi: 10.1007/s00125006-0309-1

20. Cumming RG, Salkeld G, Thomas M, Szonyi G. Prospective study of the impact of fear of falling on activities of daily living, SF-36 scores and nursing home admission. J Gerontol. 2000;55:299-305, https://doi.org/10.1093/gerona/55.5.M299

21. Said G. Diabetic neuropathy - a review. Nat Clin Pract Neurol. 2007;3:331-40, doi:10.1038/ncpneuro0504

22. Farias Feitosa T, Queiroz dos Santos Dantas M, Brito da Silva C, Pereira A. Monofilament for preventing the diabetic foot: an integrative review of the literature. Online Braz J Nurs. 2016;15:291-301. Available from: http://www.objnursing. uff. br/index.php/nursing/article/view/5277

23. Dros J, Wewerinke A, Bindels PJ, Van Weert HC. Accuracy of monofilament testing to diagnose peripheral neuropathy: a systematic review. Ann Fam Med. 2009;7:555-8, doi: 10.1370/ afm.1016

24. Baraz S, Zarea K, Shahbazian HB, Latifi SM. Comparison of the accuracy of monofilament testing of various points of feet in peripheral diabetic neuropathy screening. J Diabetes Metab Disord. 2014;13:19, doi: 10.1186/2251-6581-13-19

25. Armstrong DG, Lavery LW, Vela SA, Quebedeaux TL, Fleischli JG. Choosing a practical screening instrument to identify patients at risk for diabetic foot ulceration. Arch Intern Med. 1998;158:289-92, doi:10.1001/archinte.158.3.289

26. Lafond D, Corriveau H, Prince F. Postural control mechanisms during quiet standing in patients with diabetic sensory neuropathy. Diabetes Care. 2004;27:173-8, https://doi.org/ 10.2337/diacare.27.1.173 


\section{Sažetak \\ DIJABETIČKA POLINEUROPATIJA I RIZIK OD PADA: STRAH OD PADA I DRUGI ČIMBENICI}

\section{Bokan-Mirković, Ž. Škarić-Karanikić, S. Nejkov, M. Vuković i D. Ćirović}

Cilj ovoga rada bio je analizirati posturalnu stabilnost, brzinu hoda i strah od pada u bolesnika s dijabetičkom polineuropatijom (DPN) kako bi se utvrdili rizični čimbenici za padove, kao i utjecaj karakteristika DPN kao dodatnih čimbenika. Uzorak od 48 bolesnika s dijabetesom tipa 2 i DPN uključen je u ne-randomiziranu opservacijsku studiju. Sudionici su podijeljeni u dvije skupine: skloni padovima (faller) i neskloni padovima (non-faller). Svi ispitanici su podvrgnuti ocjeni pomoću sljedećih testova: Functional Reach Test (FRT), Tinetti Falls Efficacy Scale (Tinetti FES) i 10-Meter Walk Test (10MWT). Neuropatija je kvantificirana pomoću Michigan Neuropathy Screening Instrument (MNSI) (Upitnik-dio) i testa 5,07/10-g Semmes Weinstein monofilament (SW-ME). Rezultati na 10 MWT i SW-ME su bili značajno različiti između skupina bolesnika sklonih padovima i onih nesklonih padovima $(\mathrm{p}<0,05)$. Trajanje DPN bilo je pozitivno povezano sa SW-ME ( $\mathrm{p}=0,005)$ u skupini bolesnika sklonih padovima. Ljestvica FES je značajno pozitivno korelirala s MNSI i negativno s 10MWT u skupini bolesnika nesklonih padovima. Logistička regresijska analiza je pokazala da je SW-ME značajno povezana s vjerojatnošću pada $(\mathrm{p}=0,0076 ; \mathrm{OR}=1,378)$. Studija je ukazala na to da je gubitak zaštitne osjetljivosti stopala značajan čimbenik za pad kod osoba koje pate od dijabetesa tipa 2.

Ključne riječi: Dijabetes melitus; Dijabetičke neuropatije; Rizik; Nesretni padovi; Posturalna ravnoteža 